\title{
Bombs and Bridges: My mother's WWII survivor story
}

\author{
Anne-Marie Turski
}

Every research undertaking usually starts with a puzzle: a central problem to be solved or question to be answered. What was it that I wanted answered in this project? Despite my mother's capacity to give, to love, and to laugh, I have, from time to time, felt sadness from within her. I had already known enough about her life to correlate portions of her past with this sadness. I suppose, because she is my mother, I had always had an interest in the study of psychological effects of war, on World War II survivors. I also felt that, even 64 years later, there was still closure to be made, on her part. LaVerda, et al, (2006, p. 1) asserted unequivocally that, "Legacies from the past are compelling reasons for studying the effects of military experiences on health". Thus I wanted to relive with her some of the life-changing moments that might help me, and others, better understand and appreciate the eternal, emotional impacts of war on individuals.

\section{About the title}

There must be thousands of published accounts of personal survival from the ravages of war, and millions of stories locked forever, in the memory banks of those who experienced them, and who are reluctant to speak about their experiences, even to their loved ones. My mother's story, set against the backdrop of this dense intertwining of triumph and tragedy, is unique because it is her story. As far back as I can remember I have been inclined to pick away at bits and pieces of her narrative as opportunities presented themselves. This curiosity culminated for me, as a 30 year-old woman, when I dragged my husband through Eastern Europe tracing the paths of both of my parents to their earliest beginnings. My father had passed away by that time, but I took great satisfaction in seeing his baptismal records in Torun, Poland; the same sense of achievement I had felt upon standing in a pasture in Poiana Stampei, Romania where my mother's family's house once stood in a forest. What I learned about my parents through that experience was that there was still so much more to learn about my parents' lives in Eastern Europe. As a grown woman I had taken opportunities where available to have informal discussions with my mother about her childhood, and her heroic flight from decimated Eastern Europe (with her five younger siblings in tow), it began to dawn on me around her $75^{\text {th }}$ birthday that my appreciation of the true gravity of her war experiences was somehow, sadly lacking.

Bombs and bridges not only seemed to capture the sights and sounds so clearly painted during my interview with her, as importantly, for the purpose of my paper, the concepts became metaphors for the tumultuous times experienced by my mother during the first 20 years of her life. Though she was exactly 81 years old when I completed an earlier draft of the paper (in 2008, see later section entitled 'Author's Notes: The Backstory'), and indeed, was some 64 years removed from the horrors of WWII, my mother can still be visibly shaken by the sound of thunder (the audible vibration reminding her of bombings, she miraculously evaded). Yet, such memories also contain happiness. They still draw a tear of joy as she replays in her mind the image of her presumed lost/dead father, crossing that bridge to be reunited with his family after the war.

This rigorous, mental fieldwork on both of our parts, which I planned to conduct, was likely to be an emotional journey for my mother and me. So in preparation for our interview, I

Cultural and Pedagogical Inquiry, 2015, 7(2), pp. 55-66

ISSN 1916-3460 (C) 2015 University of Alberta

http://ejournals.library.ualberta.ca/index.php/cpi/index 
set the kitchen table not only with my recording device, notebook and pens, but as importantly, a box of tissues. In her article, "Personal Writing in Social Research", Marjorie L. DeVault's chapter (in Hertz [Ed], 1997, p. 217) suggested that social scientists don't take writing as seriously as those who make a living with words (Hertz, p. 217). However, I was committed to capturing my dear mother's words and, in turn, transcribing, condensing, paraphrasing and weaving them into the epic-like story, which I believed was waiting to be told.

I had to curb my zeal, however, for it was not my story to tell - only to bring forward. Hertz' (1997) excellent collection of articles, in "Reflexivity and Voice" proved to be a major source of information. For ease of reference, and in order to, avoid unnecessary duplication, in citing some of my key sources, I have clustered together, the authors who contributed significantly to my research whose work is included in Hertz's book, in the Reference section of my paper.

Hertz' book focuses on the balance that I would require, in my foray into ethnography. The book makes the important distinction between interpreting experiences (reflexivity) and accurately capturing the presence of the ethnographic subject (voice, Hertz, pp. $49 \& 195$ ). Furthermore, as DeVault (in Hertz, p. 218) points out, "personal writing" in this context is there to "frame the substance of an analysis". This perspective resonated with me because it upheld the ability to strike a balance between reflexivity and voice. I also felt certain that some of my own writing and interpretation were going to be necessary, in order to, more fully, tell my mother's story in the graphic details which it deserved.

\section{Methodology \& Controls}

Two of Hertz' authors Adler and Adler's (pp. 21-44) itemized several highs and lows associated with their research project conducted with their children and their children's friends. Although I too was working with a loved one as my subject, I avoided many of the limitations they encountered, simply because, my formal interview was to be restricted to one hour, as opposed to their seven year project. Moreover, I was going to interview a single person - my mother - rather than the dozens of individuals who participated in the Adler and Adler research project. These factors reduced the research threats that Adler and Adler referred to as role confusion and role pretense (pp: 31-32). My mother could easily comprehend my role as a researcher and she was quite comfortable speaking candidly with me.

Aside from selecting a subject, preparation included logistical matters; research on best practices in ethnography within family, background research of subject, development of interview guidelines, and preparation of a written paper, and an oral synthesis for presentation to my peers enrolled in the same research course. Fortunately, my research had begun when I was a child. Familial osmosis aside, I had begun journaling notes about my parents years ago. This "quarrying", described by DeVault, would allow me to "write myself into my project" (in Hertz, p. 219-220). To this end, I began rummaging through desks, boxes, filing cabinets, and closets throughout the house, assembling a body of evidence (artifacts) from which to create my interview notes and guidelines. Key to my research was the journal from the aforementioned trip to Eastern Europe in 1997. My fieldwork, which ultimately allowed me to stand where my mother would have stood as a young girl in Romania, was going to be instrumental in setting the scene for my interview. In addition, notes that my siblings and I had assembled previously, as tribute to my father, at his funeral in 1991, had also captured key milestones in my mother's life. In short, I wanted the resultant discussion with mom to bear fruits of inspiration that anyone could use to help them understand more clearly, behaviours, perspectives, and perceptions of war survivors.

Cultural and Pedagogical Inquiry, 2015, 7(2), pp. 55-66

ISSN 1916-3460 (C) 2015 University of Alberta

http://ejournals.library.ualberta.ca/index.php/cpi/index 
I realized, prior to assembling my subject research material that a one-hour interview would barely scratch the surface of my mother's life, and yet I wanted to provide at least a glimpse into all stages of her life from her earliest memories. With this objective of producing maximum volume inside a limited time period, I decided to divide my interview into 4 main chronological eras of focus within my mother's life: 1) Pre-WWII; 2) WWII-Canadian immigration; 3) Motherhood; 4) Grandparent-Great Grandparenthood. While I acknowledged that it would be difficult to maintain the discipline required to keep discussion within these sections to an allotted time period, I felt that certain controls were essential in order to generate the information in a meaningful way.

In addition to time constraints, I also had to be conscious of controlling my voice, and to deliberately restrain myself from either explicitly, or implicitly, trying to influence the story waiting to be told. If this was truly going to document my mother's life, then I had to let her tell her own story it her way. Charmaz and Mitchell's chapter (in Hertz, pp. 193-194) refer to the "animus of storytelling" as the author's personal interpretation of the data. They describe the author's voice as flawed but necessary in ethnography. In reflection on the research process (specifically, during, the interviewing process, analysis of data, and writing of my final paper), I began to understand what they meant. I felt, a real need to communicate in my voice. Thus, considerable restraint from being any voice at all, needed to be respected in some parts of the interview (p. 194). On the other hand, there were times in which my mother became emotionally overwhelmed and required assistance in articulating her thoughts. In such cases, I felt compelled to assist her in finding the right words without putting words in her mouth. This sort of interpretive assistance would occur infrequently during my interview, however, when it did occur, I quite confidently fell back on the sentiment of ethnographers Charmaz and Mitchell (in Hertz, p. 194):

We go and see and sometimes join; we ask and listen, wonder and write, and tell our stories, not necessarily in that order. We believe that these simple acts of outward inquiry and inward reflection together with effort and creativity will give us something to say worthy of sharing.

I had no doubt that my mother's story, with or without my interpretation, was worth sharing. I guess there was a part of me, however, which wanted to somehow protect her. I had to cognitively work to keep this instinct at bay, in order to, allow the truth out. In this sense, I think that I took on more a role of being, a biographer, as opposed to, being an ethnographer. As Waite (2003, p. 1) suggested, I wanted to create a metamorphosis of the evidence, rather than influence it.

\section{The Interview}

What was going to be the metamorphosis of the vast pool of evidence trapped within my mother's memory? Knowing a little of what she had been through in her life, my mother had always struck me as perhaps, being, the most willful person I had ever known. It was ironic, therefore, that I had perceived from her, periodically, a sense of tremendous loss. In my interview of November 15, 2008, I began to learn even more about her life. I realized, for the first time, just what impact the war had had on her very being.

Tragedy had been a constant companion throughout most of her life, but my mother's earliest memories were the stuff of storybooks.

I remember very vividly, it was Christmas Eve, as this was celebrated much more than

Christmas day...we, my sisters and I, and dad, were in the choir, so we would always go

Cultural and Pedagogical Inquiry, 2015, 7(2), pp. 55-66

ISSN 1916-3460 (C) 2015 University of Alberta

http://ejournals.library.ualberta.ca/index.php/cpi/index 
to church. Mom had everything in the dining room, which was always locked before Christmas. When we arrived home from church, she would disappear into that room and then fling open the door. And there would be the beautifully decorated tree, candles, and sparklers. It was dangerous, because of the fire hazard, but it was Christmas. Of course, we would sing "Silent Night". Then we would have dinner, open up all of our presents, and then play games. It was wonderful.

I asked my mother why her family was barred from the dining room leading up to Christmas, thinking that it had something to do with the volume of work her mom had hoped to achieve and that she wanted disturbance and destruction prevented.

We didn't see the room for two weeks because, as she (mother) said, "If the children see the tree every day before Christmas then it is not a big deal". And I still remember that tree. It was so beautiful. We would help her make some of the decorations...Walnuts were dipped in a gold-coloured liquid, folded paper figures were linked together to form garland... but we didn't see any of it until Christmas Eve. It was a very beautiful tradition. Vivid pictures filled my mind as my mother described a childhood that she categorized as "comfortable but not rich" (Interview). While she may not have considered her family to be in an upper class bracket, financially, she recalled occasions in which Romania's ruling monarch, King Carol II and his son, Prince Mihai, would visit and together with my Grandfather, they would go deep into the woods on hunting expeditions (Interview). King Carol II, I would learn later, from my mother and some additional research, was an innovative and controversial leader (Quinlan, 1995, p. 34).

Aside from brushes with royalty and memorable Christmases, my mother recalled a loving but strict and protective home-life in which, she stated, "my mother was the heart and my father was the brains" (Interview). In addition to being the "brains", there appeared to be little doubt who was in charge within the household.

As children we were very scared of him. VERY scared. I mean, my father was for education. He always checked our grades and often participated in our homework...I was called "stupid" because I could not grasp math. Louisa (sister) was very good in math, and she learned languages very quickly... and she was also very athletic.

During this passage, I began to sense a longing for acceptance in my mother's words, but not in her demeanor or mannerism. I questioned her on the psychological impact of being called "stupid" by her own father, however, she immediately came to his defense in describing his best intentions and staunch protection of his children from outside forces.

There was one incident in school, I was in grade 4 or 5 , and my teacher, she just hated me because she knew we were from German descent, told me to "march like a Romanian" as she tugged at my braids. One day I had to excuse myself to go to the bathroom, but she wouldn't let me and so I had an accident. The whole class just laughed and so I ran away from the school. I went to my mom, who told Olympia (maid) to go to dad's office and bring him home. My dad took me by the hand to the school...He first talked to the teacher, but I couldn't hear because the door was closed. Then, he went and talked to the principal. There I could hear him screaming through the closed door. I had never heard him like that before and I was so scared. But you know, the next day, the teacher was not there. She had been fired.

Hearing my mother recount this incident made me sad. As well, it revealed to me something that I had known but not really cognitively acknowledged. My mother and her family had been subjected to ethnic discrimination at an early age. I would learn, not only through the

Cultural and Pedagogical Inquiry, 2015, 7(2), pp. 55-66

ISSN 1916-3460 (C) 2015 University of Alberta

http://ejournals.library.ualberta.ca/index.php/cpi/index 
interview, but also through random discussion with my mother throughout my life that this theme had indeed been recurrent no matter where she had lived - for most of her life. In Romania, she and her family were ridiculed due to their German descent; in Austria, the prejudice was targeted at their Romanian background; and finally, during her first few years in Canada, she would hear occasional calls of "(expletive) D.P. (Displaced Person)" (Interview). Having said all this, there were hints that perhaps her own father had exposed her to statements and acts of racism.

He found us (children) walking barefoot in the grass and we got whipped. Because, as he said, "we are not gypsies, we are not allowed to go barefoot".

A gentler, more well intentioned, albeit still prejudicial father, emerged as my mother described her entry into teacher's college in grade 9.

He (father) was so proud. He bought me a case in which to put my books and it was all leather, very good craftsmanship. And he gave me money and I remember distinctly him saying to me, "Remember this, tell me with whom you go and I will tell you who you are." In other words, he was saying not to get involved with people with lower morals."

It was around this time in her life, as my mother entered her teens, that life shifted dramatically from the comforts she and her family had enjoyed, up to that time. She was first made aware, through overhearing discussion between her parents that Jewish acquaintances were beginning to flea Romania (Interview). Her mother and father, primarily of German descent and fearing an invasion by Russia, decided that it was prudent to flea their home, as well, and take refuge at my mother's grandparent's home in Bucovina, a mountainous region of Romania. They would never return to the home in which they had built such wonderful and vivid memories. From that point, and for the subsequent several months, my mother's memory of the exact chronology of events is a little blurry.

We stayed there (Bucovina) until it was time to go. Where were we supposed to go...there were many, many Germans. I remember we were on a train and we traveled a lot. Czechoslovakia, Poland...Mom had (my youngest sister) in Poland and that's when we lost her. The Germans had bombarded the bridge and Mom was taken to a hospital by the Red Cross. And Dad was taken to the German army. And so we were alone (my mother and her three sisters and two brothers).

Suddenly, at the age of 15 , fate had made my mother responsible for her brothers and sisters in the epicenter of what would become one of the most violent stains on the fabric of human history - World War II.

I knew from this point forward in the interview, that the content was going to be bleak and yet harrowing and inspirational. Much of the content which followed I had heard several times on various occasions listening to my mother throughout my life. Some of it, even after having heard it several times, still made me emotional, and yet I felt it important to be chronicled.

My mother's life, for a period of several months, as the eldest sister and unofficial guardian of her 5 younger siblings, consisted of hopping from train to train, following a moving refugee camp, dodging war zones and international borders (Interview). They didn't bathe for months on

Cultural and Pedagogical Inquiry, 2015, 7(2), pp. 55-66

ISSN 1916-3460 (C) 2015 University of Alberta

http://ejournals.library.ualberta.ca/index.php/cpi/index 
end, became afflicted with measles, ear infections and lice, and subsisted on a paltry bowl of watered down soup once a day (Interview). If there was any mercy, it seemed as though they would be spared the sight of death, until one day late in their journey.

There were times when a train we were on received gunfire, but no one was killed. The tragedy was, there was one incident with a woman behind me with a baby. Her boys would sleep on the floor and I always heard her crying. One day, the man who took care of the train came to her and said, "How come I never hear the baby?" He insisted that she unwrap the blankets in which the baby was kept and you know what? The baby was dead.

This was one of the points of the interview where I felt as though a deep and troubling wound was going to be inevitably re-opened. I was tempted to stop the tape and clutch my mother's hand. I was reminded of Margaret Willard-Traub (2007, p. 205), who, in her article, "Scholarly Autobiography: An Alternative Intellectual Practice", succinctly captured my predicament, stating, "Being accountable also means at times writing against the disciplinary grain and at times writing in the company of painful memory".

Although I had never heard this dark memory from my mother, I was lead to believe by the deep dark tone in her voice, that there was more to it. I asked if mom was okay to proceed. She nodded and continued.

You know what they made her do? When the train crossed a bridge over a lake, they made her throw the body out the window. (Subject becomes emotional) It made such an impact on me. I became hysterical.

At this point in the interview, I felt as though I had to pause in order to maintain my own composure. I had experienced personal tragedy in my own life and this story was beginning to feel a little too close to home. I quickly moved along to her next memory. I was riveted, not as an aspiring ethnographer, but as a daughter witnessing my mother's amazing life through her eyes. The only thing standing between me and early 1940's Europe was the understandable limitations with her memory. Was I wrong to push the conversation along and away from the troubling infant recollection? Perhaps my mother would have wanted to reveal more from that dark day on the train. Was it selfish, or unethical, to alter the outcome? I felt these ethnographical compromises as voices in my head, but I was quite firm with my decision to move ahead.

My mother and her siblings would witness additional and more gruesome reminders that war was unleashing its cruel vengeance all around them, as they continued in their grueling journey towards finding a permanent and safe refuge.

Bad Ischl, a small Austrian border town must have appeared as an oasis in the wake of the ruin of Poland, Czechoslovakia, and Germany. My mother and her siblings had endured almost two years keeping one step ahead of the battlefront. Train-hopping, refugee camp squatting, scarlet fever, bombs and gunfire had become unwelcome norms of their lives and finally, they had crossed the border into a country which, by that time would have been liberated from German rule by the Allies (Keyserlingk, 1988, p. 144). They were holed up in a school gymnasium, where they would stay for several more weeks before being the last inhabitants left (interview).

Cultural and Pedagogical Inquiry, 2015, 7(2), pp. 55-66

ISSN 1916-3460 (C) 2015 University of Alberta

http://ejournals.library.ualberta.ca/index.php/cpi/index 
By that time we were the last ones there. Farmers and villagers had come to claim orphans, but no one wanted five kids. So they began picking us as individuals as if we would willingly allow our family to be broken up. Well, you should have seen me. I was screaming and waving my arms, resisting their aggressive attempts to take us in different directions. "You don't know where your mom and dad are", they'd say. But I said, "I don't care...I know I'll see them again and I want to tell them that I saved my family."

Shortly thereafter, my mother and her siblings were all invited to stay with a wealthy and childless Austrian couple that offered them the entire upper floor of their two-storey home. They had their own bathroom, within which they each took baths for the first time in 2 years (Interview).

Despite their displacement from their homeland of Romania, their odyssey through Europe, fleeing for their lives, my mother would remember Bad Ischl as a beacon of good luck. It was while living in that upper flat that all five children began to re-assemble their lives, and their mental and physical health. More significantly it was in that little home where three significant events were still to take place. Firstly, a heavy knock at 4:00AM one morning brought their mother and hitherto unmet baby sister "home". Secondly, their Papa, after having forcibly been conscripted to serve in the German army for the previous five years, literally came stumbling over that bridge and down the street, which passed by their home. Tears of joy would be shed a third time, when an end to the war was declared (Interview).

My intention, to cover the life and times of my mother in a one-hour interview was suddenly feeling like quite a naïve venture. We had already been talking for well, over sixty minutes. At this point in the interview process, my mother was telling me of when she would have been no more than 20 years old. Given that she was 81 when I conducted my interview for this project, it was quite obvious that my math was not going to add up. However, I felt that I had to operate within the criteria that had been set out in the assignment description. Fortunately, at this stage of the interview, we had landed on a fairly significant milestone. It was a significant marker, not only, in my mother's life, but indeed, even in that of human history, the end of WWII.

Additionally, upon revisiting my initial research objective, I felt as though I had gathered enough material to begin linking the long-term effects that the Second World War had had on my mother with some of her present behaviours.

\section{Retrospective}

Research is the pursuit of truth. If quantitative research tells us "what" or "how many", qualitative research must tell us "why". Ethnography, as a form of qualitative research, helps us explain why. It provides us with snapshots of lived experiences. It offers perspectives of the course of human history, as seen through the eyes of its participants. There is no one I know, living today, who has as much experiential data stored in her memory as my mother. For years I have not only felt the desire, but the obligation, to capture even a fraction of that data for the sake of my own curiosity of my origins, but also for that of my daughter and future generations. There were, however, challenges and unexpected obstacles that I encountered.

Cultural and Pedagogical Inquiry, 2015, 7(2), pp. 55-66

ISSN 1916-3460 (C) 2015 University of Alberta

http://ejournals.library.ualberta.ca/index.php/cpi/index 
Penetrating that enormous databank of memories in a meaningful, respectful way, within the constraints of a one-hour interview proved to be an impossible goal. A sense of panic and diminishing returns begins to set in when you feel as though you may not be acquiring the most valuable material. In hindsight, I was somewhat amused at my naïveté in assuming that I could possibly do justice to my mother's entire life in a one hour interview. However, even after I had let go of that over-arching pursuit, I began to wonder, as the interview progressed, if I would even be able to complete a more modest goal that of documenting even her first quarter century of life.

In reviewing the recorded audio, video and transcripts I began to see some of my rookie mistakes as an ethnographer, colliding with the inherent perils of interviewing my own mother. My line of open-ended questions, paired with my fascination in her story-telling, lead to extensive responses, some of which were beyond the scope of the research objective. This part of the experience provided me with a deepened appreciation for the work of ethnographers - whether or not their research subjects are loved ones or strangers. I believe this is where the balance between reflexivity and voice reaches a crescendo. The interviewer must be skilled in interpreting the story from the storyteller, while keeping it framed within predetermined guidelines. Ethnographic privilege, as Michalowski (in Hertz, p. 50) surmises, provides the ethnographer with the power to frame the subject's voice for the consumption of others (Hertz, p. 50). In hindsight, perhaps, my personal attachment to my subject had blurred the guidelines even more, than if, a complete stranger had conducted the interview.

Despite my admission that I somehow let personal interest compromise my discipline in time management during the interview, I can also attest to the notion that, without the level of selfdiscipline I was able to achieve, the interview would have been longer still, possibly continuing for hours or days. It was a struggle for me to resist the temptation to probe with follow-up questions simply to adhere to a time constraint. Additional probing, I'm sure, would have provided deeper examination of topics, leading to enhanced understanding and trustworthiness of accuracy (Dobbs, et al, 2008, pp. 518-519).

A second major challenge in my project involved not only my handling of the voluminous information available, but also my mother's capacity to process it in the moment. As some of the above excerpts indicate, beyond the historical accounts of casualties of war and its multiple levels of destruction, war is chaos. While I had unfairly wished that my mother had kept a journal of her experiences, I would have to pardon her as she was a little pre-occupied in the task of keeping herself and her siblings alive. However, it is what it is, and ethnographers need to be able to extract and unravel the evidence in a meaningful way. To this end I would recommend, as a learning from my fieldwork, that subjects are given time to prepare for interviews as well. I had initially considered sending my mother a list of questions and topics upon which our conversation would be based, however, I hesitated, as I believed her raw spontaneity would bring greater value to the interview. I also took some comfort in Cohler's (2008, p. 11) study, which found that women, particularly women having survived emotionally charged experiences decades ago, were very capable of vivid recall due to their concern with a relational world, in which the quality of relationships was of paramount importance.

Cultural and Pedagogical Inquiry, 2015, 7(2), pp. 55-66

ISSN 1916-3460 (C) 2015 University of Alberta

http://ejournals.library.ualberta.ca/index.php/cpi/index 
Related to the concern brought forth above, was my general lack of knowledge of the historical landscape of the era in which I had chosen to research. While it is one thing for ethnographers to consider themselves interpreters of history, they must do so with some knowledge of the history they hope to interpret. Michalowski (in Hertz, p. 52) credits Bruner's argument that there is a dominant discourse in ethnography from which "a narrative structure emerges". While I saw the structure of my findings emerge, I felt a need for factual evidence to support the narrative. I thus endeavored to bone up on World War II history while I was assembling the data for this written project. The depth of my ignorance of historical fact was compounded by the sheer passage of time from which the interviewee was being asked to recount.

During the interview, for instance, my mother had referred to Austria as an independent state within which she and her family finally found solace from the war. My somewhat shameful lack of WWII knowledge prompted me to seek a chronological connection of fact. Had Austria been spared the malice of the Third Reich and left to its own control? I must admit that my knowledge of WWII Austria was limited to the, "The Sound of Music", which, while considered a crown jewel of film making, could hardly be my grounds for historical fact. And while my mother lived through WWII, she had more pressing things to attend to than chronicling the war as it unfolded.

It was thus my responsibility to conduct at least minimal secondary research, through which I discovered that Austria had been annexed by Germany in 1938 before being officially handed back to the Austrians in 1945 by the Allies (Keyserlingk, 1988, p. 144). This was an important shred of evidence for me to discover, as by the combined calculations of my mother and I, we were able to determine that she and her family arrived in Bad Ischl, Austria in 1944. How could it be a safe haven for war refugees if it were still controlled by Germany? The work of historians such as, Keyserlingk, helped explain that the transition back to a self-governing Austria actually, began in 1943. At the time when the grip of Hitler's Germany began to loosen proportionally, due to, the growing momentum of the full retaliation by the Allied Forces (Keyserlingk, pp. 140147). All of which supported my notion that, given the depth and historical weight of the era I was attempting to interpret as an ethnographer, I was out of my element as a historian and thus ran the risk of losing factual evidence in the ethnographic process.

There was one other key challenge in my experience of assembling and conducting my research project. This concerned balancing the sensitivity of the emotionally charged memories of my mother (and my instinct to protect her) with my objective as a researcher to exhume and reveal her feelings. However, it was indeed those very memories that would form the substance of my findings today so that they could be shared tomorrow. In other words, the memoirs could only be told through the memories of the key participant. In "Two Lives, Two Times", Cohlar (2008, p. 1) cites 12 sources in arriving at his opening statement: "Writing a life-story or memoir brings together into a personal account a presently remembered past, experienced present and anticipated future that fosters our sense of continuity of self or identity". To edit my questioning, much less the responses of my mother, in order to protect her or future readers from the pain associated with various content, would be tantamount to tampering with history - clearly not the mandate of an ethnographer.

Less significant, but noteworthy, hindrances occurred during this research project. Logistically, it made the most sense to interview my mother at her home. As Adler and Adler (in Hertz, p. 22)

Cultural and Pedagogical Inquiry, 2015, 7(2), pp. 55-66

ISSN 1916-3460 (C) 2015 University of Alberta

http://ejournals.library.ualberta.ca/index.php/cpi/index 
assert, interviewing subjects in their natural environment would logically elicit more natural responses. That being said, in the rich tradition of her own mother, my mother's home is her family's home, and it is rarely absent of siblings, children, grandchildren or great grand children. Thus, in order to secure a quiet time in a busy household I was compelled to request that my mother inform any would-be visitors that she (and her house) were out of bounds during, the date and time which had been pre-arranged for our interview. One must appreciate how difficult it would have been for my mother to say "no" to anyone, in order to understand that this otherwise minor request may have created some discomfort, and sense of compromise, in her mind.

\section{Conclusion}

The experience of interviewing my mother as a form of mental fieldwork for this research paper was filled with a range of emotions. In the end, it was both rewarding and exhausting. I contemplated whether or not it might have been easier had I not known my mother - if I had endeavored to study long-term effects of World War II on a survivor with whom I had no acquaintance whatsoever. While this may have forced a greater degree of objectivity, meaning emotional distance from the subject, I'm not convinced that achievement alone would offset the value gained by intimately knowing my primary subject. Katherine Irwin (2006, p. 160) writes,

"Fieldwork, in many respects, has been considered exceedingly edgy. As outsiders angling for insider knowledge, professionals dependent on personal relationships for data, and members of research settings as well as the academy, field researchers ride the lines between and across multiple boundaries, and the journey, as many have attested, can be emotionally and existentially uncomfortable".

While Irwin's research subject was a man who would become her husband, and her research topic had more to do with sociological deviancy than the horrors of war, I nevertheless felt the edginess she describes, as I made my way through my data gathering. "Where was this going?", I thought, as I found myself wading through the emotions that my mother may have been carrying alone for decades. "What have I gotten us both into?" The voices became distracting, despite the relative small-scale nature of my ethnographic study. There were moments, during my limited discussion, where I questioned whether or not I would be able to identify and surgically extract the most valuable material from such an amazing, personal story. Reinharz (in Hertz, 1997, p. 18 suggests that researchers do not really know where the value of their research project will emerge prior to the fieldwork. I was not sure what parts of my interview with my mother were going to provide the answers outlined in my objective, nor which would become dead ends. I suppose I expected some elements of both, however, I was relieved, upon reliving the interview experience through the magic of digital videotape, that ethnographic composure had prevailed and a vast and wondrous pool of raw life experience had been captured, on the tape.

It would be my wish to build on this interview with my mother and actually conduct several more, of course, with her approval, in order, that I could drill down deeper into her memories, from one fascinating stage in her life to the next. I would also want to expand my list of subjects and respectfully approach my mother's siblings. Their memories, juxtaposed with those of my mother would most certainly create the collective remembrances Cohler $(2008$, p. 4) talks about in "Two Lives, Two Times". It is not that my mother's perceptions alone could not fulfill the objectives of this research project; subject number expansion (namely, in the number of interviews conducted), and additional fieldwork, would have deepened the human dimensions, Cultural and Pedagogical Inquiry, 2015, 7(2), pp. 55-66

ISSN 1916-3460 (C) 2015 University of Alberta http://ejournals.library.ualberta.ca/index.php/cpi/index 
and, at the same time, strengthened the physical components (e.g., an actual field trip to Eastern Europe to trace her journey across Europe).

Thus, the end, as is the case in most research projects, becomes a new beginning. While I feel satisfied having met the criteria of a graduate study assignment, I am motivated to increase the scope of this project in order, to achieve a personal goal, perhaps resulting in producing, a more complete biographical account of my mother's life in Eastern Europe, during the war. This is not an epiphany, suddenly having revealed itself as a result of my mental fieldwork experience. I have always believed, albeit with some degree of bias, that my mother's entire life story is the kind of material that makes best-selling biographies and epic motion pictures. However, my recent compulsion to explore her story further, probably has as much to do with my own desire for a deeper self-understanding, as it does with a desire for a more compassionate understanding of my mother. Reinharz (in Hertz, 1997, p. 18) suggests that understanding self, is perhaps the most valuable tool in ethnographic fieldwork. Perhaps the most significant learning from my experience then, is as much about me and my compulsion to tell the human story, as it is about the singular and fascinating story of my mother - an extraordinary woman.

\section{Author's Notes: the backstory}

An earlier, less complete, and far shorter version of this paper was produced to meet the requirements of a graduate qualitative research methods course: "Oral and Narrative Histories". The earlier paper, gave me the opportunity to give my mother's story its due. I was very surprised when in early 2015, seven years after submitting "Bombs and Bridges", that I was contacted by Cecille DePass, and invited to revamp the paper, and to submit it formally, for consideration, in the online, academic journal: "Cultural and Pedagogical Inquiry (CPI)".

I agreed to obtain my mother's consent to publish her story, in the public domain. Preparing this paper for CPI, has re-opened some of the wounds which my mother will always carry from her WWII experiences. With bravery and dignity, Waltraud Turski, my mother, re-read the paper. She shared it with her living siblings, openly recalling the terror and triumphs, which were her war experiences, 70 years earlier.

Knowing that her story would be published, I decided to remove the names of my mother's siblings, in order to respect their rights to privacy. On my part, I became quite emotional when I re-read her story. So much has happened in my life since I first wrote her story in 2008. I am now almost 50, I have given birth to my second daughter, and am able to walk with Gabby, now 5, and my older daughter, Eva 9, to their nearby schools, with the taken for granted, smartboards, Ipads, and lunchrooms.

I lead a life, which stands in such stark contrasts to the events in my mother's story. On any given day, my greatest peril, is encountering an over-zealous skateboarder on the sidewalk - hers was an armed Nazi soldier. Perhaps it is wrong to draw comparisons between my otherwise safe, sheltered and abundant life to that of my mother's. This reflection, however, does give me pause to be grateful for my life, and the mother I was given.

Accordingly, this article is dedicated to the indomitable, WWII survivor, Waltraud Turski-my mom.

Cultural and Pedagogical Inquiry, 2015, 7(2), pp. 55-66

ISSN 1916-3460 (C) 2015 University of Alberta

http://ejournals.library.ualberta.ca/index.php/cpi/index 


\section{References}

Cohlar, B., Two Lives, Two Times; Life-Writing after Shoah, 2008, Narrative Inquiry 18:1, Chicago: John Benjamins Publishing Company.

Dobbs, D., Eckert, K., Rubinstein, B., Keimig, L., Clark, L., Frankowski, A. Zimmerman, S. 2008. An Ethnographic Study of Stigma and Ageism in Residential Care or Assisted Living. The Gerontologist, 48(4), 517-26.

Hertz, R., (Ed). 1997. Reflexivity \& Voice. Thousand Oaks, CA: Sage Publications.

Key chapters in Hertz (Ed) are as follows:

(i) Adler, P.A. \& Adler, P. Parent -as- Researcher: The Politics of Researching in the Personal Life. (pp. 21-44).

(ii) Charmaz, K. \& Mitchell, R.G. The Myth of Silent Authorship: self, substance and style in ethnographic writing. (pp. 193-215).

(iii) Devault, M. L. personal writing in social science: issues of production and interpretation. (pp. 216-229).

(iv) Michalowski, R.J. ethnography and Anxiety: Field Work and Reflexivity. (pp. 45-69).

(v) Reinhartz, S. Who Am I? The Need for a Variety of Selves in the Field. (pp. 1-20).

Irwin K. 2006. Into the Dark Heart of Ethnography: The Lived Ethics and Inequality of Intimate Field Relationships. Qualitative Sociology [serial online]. Summer 200629 (2): pp. 155-175.

Available from: Sociological Collection, Ipswich, MA. Accessed December 3, 2008.

Keyserlingk, Robert H. 1988. Austria in World War II: An Anglo-American Dilemma. Montreal: McGill-Queen's University Press.

LaVerda, N., Vessey, A, Waters, W. 2006. Use of the Veterans History Project to Assess World War II Veterans' Perceptions of Military Experiences and Health, Military Medicine; 171, 11; ProQuest Medical Library, p. 1076.

Quinlan, P. 1995. The Playboy King: Carol II of Romania. Westport: Greenwood Press.

Willard-Traub M. 2007. Scholarly Autobiography: An Alternative Intellectual Practice. Feminist Studies [serial online]. Spring 2007, 33, (1):188-206. Available from: Sociological Collection, Ipswich, MA. Accessed December 3, 2008.

Waite, P. 2003. Biography and history: reflections of a biographer-historian. Canadian Issues, Montreal.

Cultural and Pedagogical Inquiry, 2015, 7(2), pp. 55-66

ISSN 1916-3460 (C) 2015 University of Alberta

http://ejournals.library.ualberta.ca/index.php/cpi/index 